Newfoundland and Labrador Studies

\title{
Fishery Reforms and William Coaker's Speech at the 1917 Social Service Congress
}

\section{Melvin Baker}

Volume 34, Number 1, 2019

URI: https://id.erudit.org/iderudit/1072440ar

DOI: https://doi.org/10.7202/1072440ar

See table of contents

Publisher(s)

Faculty of Arts, Memorial University

\section{ISSN}

1719-1726 (print)

1715-1430 (digital)

Explore this journal

Cite this document

Baker, M. (2019). Fishery Reforms and William Coaker's Speech at the 1917 Social Service Congress. Newfoundland and Labrador Studies, 34(1), 158-170. https://doi.org/10.7202/1072440ar viewed online.

https://apropos.erudit.org/en/users/policy-on-use/ 


\section{Fishery Reforms and William Coaker's Speech at the 1917 Social Service Congress}

Melvin Baker

\section{Introduction}

In December 1917 the newspaper of the Fishermen's Protective Union (FPU), the Evening Advocate, boasted that FPU President William Coaker was "the most powerful political and commercial factor in the Dominion." ${ }^{1}$ Since founding the FPU in 1908 he had dedicated himself to seeking social, economic, and political improvements in the working and living conditions of Newfoundland fishermen. ${ }^{2}$ In 1913 the FPU had entered active politics through the establishment of its Union Party and in the general election that year won eight seats. Along with the seven seats won by the Robert Bond-led Liberal Party, ${ }^{3}$ the Union Party formed the Opposition in the House of Assembly to the re-elected government of Prime Minister Edward Morris. ${ }^{4}$ In July 1917 Morris persuaded the Opposition, led by Liberal William Lloyd and Coaker, to join him in a coalition government (the National Government which lasted from July 1917 to May 1919). ${ }^{5}$ The coalition was needed to better manage Newfoundland's general participation in the First World War and to deal with the economic problems the war wrought on the economy and fishery. Coaker became a minister without portfolio in the National Government. 
Thus Coaker, the country's leading progressive reformer, became also a leading member of government. ${ }^{6}$

The formation of the National Government had also put the scheduled election into abeyance. Consequently, the FPU's election platform, which surely would have focused on fisheries reforms, was not released. However, later in 1917 Coaker did give a speech that surely reflected the types of reforms that would have been in that election manifesto. He spoke at the meeting (or Social Congress) of religious and community leaders in St. John's organized by Church of England, Presbyterian, and Methodist Church leaders and held between 8 and 11 October 1917. ${ }^{7}$ The Congress opened to a full audience in the Methodist College Hall under the chairmanship of Governor Sir Walter Edward Davidson, ${ }^{8}$ who "felt sure that public opinion was behind this great evangelical movement towards social reform. The gentlemen here tonight were the professors of applied Christianity." This Congress dealt with social and moral issues facing the Newfoundland people "in the interests of the Social Awakening." "Social Awakening" was a battle cry of social gospel advocates, referring to an awareness of the social dimension and concerns among ethically attuned Christian contemporaries. ${ }^{9}$ Congress organizers brought in prominent speakers from Canada and the United States to discuss social and moral issues. ${ }^{10}$ The Congress, as reported by the St. John's Daily Nerws, was viewed by contemporary progressive forces in St. John's as an "event of very great importance. Distinguished visitors, experts in the promotion of the Social Welfare movement, have come to our city to discuss with us some of those pressing and tremendously vital problems which are common to all countries, and from which even in our small community we are not free." ${ }^{11}$ Similar social congresses had been convened elsewhere by religious leaders in Europe and North America, establishing a groundswell of solidarity among religious and civic leaders to address the urgent social questions faced by industrial society and its urban needs. The aim of the St. John's Congress, the Daily News noted in welcoming the visitors, was to organize a Social Service Council in Newfoundland. ${ }^{12}$ 
In his speech, Coaker summarized the problems that had so longed plagued the fishery and offered suggestions for fishery reform, such as standardization of the fish cull and better marketing of Newfoundland fish. The speech reflected the principles embodied in the FPU's 1912 Bonavista Platform and revised at Catalina in December 1916 at its Annual Convention. The FPU had previously not made this revised platform available; it had been withheld publicly until the date had been called for the general election scheduled to be held in 1917. The formation of the National Government in July 1917 postponed the calling of an election for a year. Some of the fishery reforms Coaker called for at the Congress were not, strictly speaking, just FPU-advocated reforms and had long been wanted as well by the fish trade in general. ${ }^{13}$ Nevertheless, his speech articulates the political stance on the country's crucial industry by the leader of one of the most successful populist political movements for social and economic reform in Newfoundland's history. It is therefore of historical significance for its vision of what steps were needed to place the fishery and the Newfoundland economy on a stronger and more viable footing. Coaker's speech, from the Evening Advocate for 10 October 1917, follows.

\section{Document}

\section{Problems Confronting the Fisheries of Newfoundland - Paper Read by Hon. W.F. Coaker, President of the Fishermen's Protective Union}

Mr. Chairman, Ladies and Gentlemen:

I have been asked to address Congress in connection with Industrial Problems, and my particular duty is to deal with problems affecting the fisheries of Newfoundland. The fisheries of Newfoundland, although prosecuted now for some three hundred years, show but little sign of depletion. The value of the fisheries vary year by year, and occasionally an overflowing abundance enables us to mark certain Banner Years, such years occur - usually about once in every eight or nine years. The last big catch of fish was recorded in 1908, when 1,800,000 
qtls were exported; this year the catch of Cod will be equal to 2,000,000 qtls, but the value to the fishermen will be nearly 300 per cent greater than that of 1908. The value of 1,800,000 quintals in 1908 totalled $\$ 4,500,000$, while this season's catch of codfish alone will reach a value of over $\$ 16,000,000$, every cent of which will go into the pockets of the fishermen. This year's cod fishery will therefore be the greatest in the history of the Colony, both in quantity and value, and will exceed in value the catch of last year - worth $\$ 10,000,000$ - by no less an amount than $\$ 6,600,000$, or, an amount greater than the total of the cod fishery in 1908. The Bank fishery, which is included in my figures, averages about 150,000 qtls annually. The total value of the Newfoundland fisheries last year was $\$ 13,740,000$, or about $3 \frac{1}{2}$ millions greater than the average of the previous five years. The total value of this year's fisheries will reach $\$ 21,000,000$ or over $\$ 7,000,000$ in excess of 1916 , equal to an increase in value of 35 per cent.

Such figures clearly show the splendid progress of the Colony, for when fishermen reap fair returns, the whole population is benefited as four-fifths of the manhood power of the Colony are engaged in the fisheries. I hope to see the average annual catch of fish equal to $2,000,000 \mathrm{qtls}$. The average so far is about $1,500,000 \mathrm{qtls}$. The problem therefore is to increase the catch per man annually and maintain fair prices, in order to keep the population comfortable and contented.

To secure an average catch of 2,000,000 qtls of codfish, it will be essential:

(1) To encourage the fishermen to utilize motor boats to the fullest extent.

(2) To encourage fishermen to prosecute the Bank fishery more extensively.

(3) To provide a continuous supply of bait fishes.

(4) To encourage the building of fishing schooners for the Labrador and Bank fisheries.

(5) To educate our boys to become producers, by instilling in the young mind a respect and admiration for the fishermen's calling. 
(6) To establish a standard cull for fish, in order to produce the best article and secure the fullest value.

(7) To expand and develop the markets abroad.

(8) To make the Fishery Department worthy of a first class fishing country.

\section{Motor Boats}

(1) If we are to derive full benefit from the motor boats, they must become general. Every man willing to engage in fishing should be enabled to secure a motor boat. Aid should be afforded those unable to secure engines. The fisherman owning a motor boat labours very little in getting to and from the fishing or trapping grounds, he reaches the fishing grounds earlier in the morning and remains there longer, therefore has more time for fishing than the man who uses sails or oars. He is fresh and active in hauling nets or, traps, as formerly the labour in rowing the skiff exhausted him physically. He is fresh and active when he reaches the stage from the fishing ground and is in good shape to prepare and cure the fish produced from time to time. The motor boat makes fishing a pleasure instead of a drudgery, it encourages the young man to engage in fishing, and in addition to removing the drudgery attending the calling, it ensures larger returns. The motor boat has come to stay, and every effort must be made to provide all with such labour-saving facilities, otherwise those not possessing them will be starved by their more fortunate neighbours. I venture to state that a fisherman's income is increased from 25 to 50 per cent by the use of motor boats.

\section{The Bank Fishery}

(2) During the past year there has been a decrease in the number of vessels and men engaged in the Bank fishery, the reasons are briefly these: the trap shore fishery, through the use of Motor Boats, deeper traps and good prices is much more remunerative than formerly and 
young men prefer trying their luck on the coast to enduring the risks attending fishing on the Grand Banks. A grievance also exists respecting the delivery to the sharemen of their proportion of the catch over the ship's rail from time to time during the voyage, the custom generally [having] been to pool the catch and leave it to the owner of the banker to dispose of. The men regard this as unfair and consider the catch should be shared as the vessel is discharged, each man to take his part as the ship's cargo is discharged. The want of a continuous supply of fresh bait is another serious drawback to the success of the Bank fishermen and steps must be soon taken to provide a reliable and continuous supply of fresh bait, which if forthcoming would probably add 25 per cent to the total catch taken by Bankers. I am of opinion that, unless measures of encouragement are afforded the Bank fishery in the immediate future, a very serious falling off will result. The number of vessels engaged in Banking in 1916 was 15 less than the previous year, this year will show a larger percentage of decline. I fear it will also be necessary to pay the men engaged a bonus per thousand fish taken, if such can be done in addition to a continuous bait supply and the distribution of fish over the rail to the crews; there is strong reason to believe that the fishery will revive and add considerably more to the annual wealth of the fisheries.

\section{The Bait Supply}

(3) For many years much has been said about a bait supply. The FPU Political Platform contains a Plank to provide a continuous supply of fresh bait. Up to the present the fresh frozen bait supply provided in this Colony has been of no importance. A string of bait depots should be erected throughout the Colony, these depots can be cheaply constructed in most cases. The salt and ice system would be sufficiently good for this purpose and depots so constructed could be erected at a cost of $\$ 2,000$ each. One hundred such depots served by half a dozen modern cold storage plants and a few large motor boats properly equipped would provide a bait supply that would enable all our local 
fishermen and Banking fleet as well as Labrador shoremen to secure all the bait they need. The whole outfit would not cost more than $\$ 500,000$. The benefits derived would be an annual additional 250,000 qtls of handline and trawl fish, suitable in every respect for the boneless fish industry, worth $\$ 2,000,000$. This amount would be additional earnings and belong entirely to the producers. The Colony would derive an annual additional revenue of $\$ 300,000$, if we compute an expenditure that would consume $\$ 1,000,000$ worth of goods, paying 30 per cent duties. ${ }^{14}$ This is a problem that will have to be solved during the next two years, if the present Administration remains in office.

\section{Schooner Building}

(4) To ensure success, and a continuation of prosperity, a fleet of fishing vessels must be provided for the Labrador and Bank fisheries. The falling off in fishing schooners during the past ten years must be as many as 500 , or, a third of the fleet which existed ten years ago. A bonus to encourage the building of fishing vessels was provided by the Colony the past year, but owing to the abnormal demand for foreign going vessels, all the Colony's building energies have been devoted to the building of large vessels. After peace is declared, every effort must be made to provide a large fleet of fishing schooners, and every encouragement must be held out to Planters and Bank fishermen to enlarge the fleet of schooners. Unless the supply of schooners is fully maintained, the Colony's financial condition will suffer, and the supply of first class fishermen will be diminished, for the floater fishermen and the Banker is the class that produces our best fishermen.

\section{Educate As Producers}

(5) The present education curriculum of our schools does not aid in preparing our boys to become producers. They are taught anything but what is essential to turn out intelligent and stable fishermen; they are not taught to love the traditions of the past. Our forefathers fought 
manfully and bravely the dangers of sealing, banking and the risks and adventures of navigating the unknown Labrador. Deeds that would cause every true boy to be proud of, can be recited by the score, yet no effort is made to impress the boys with a love of the deeds of their forefathers or encourage an interest in the calling of the fishermen. There is no life open to the average young man that can excel that of being owner and master of a modern schooner suitable for the Grand Banks or fishing on the Labrador Coast. No men in the country today are more independent than our fishermen planters, who own their own schooners, boats, fishing outfit and premises; yet in spite of this, the past decade has witnessed an almost wholesale desertion of the fisheries by our young men. For some reason or other the calling has lost for them the attraction it had for their ancestors. The young Newfoundlander of the present day appears to have no ambition to be the owner and master of a schooner, to acquire and own motor boats, cod traps, land store and flakes. He regards the occupation of his forefathers as something to be held on to only while he seeks something he considers better and the moment he thinks the opportunity arrives he is gone. The professions, trade, the civil service are every year taking to their ranks men who might have been successful fishermen planters, had they chosen to pursue the avocation of their forefathers. The fisheries have not been given the attention they deserve or made as attractive as they might be, consequently, the young men have become indifferent towards the calling of their fathers. I have said before that the education our boys are receiving in the public schools of the country today tends to make them anything but fishermen. Where for example today can one find a decent text book on the Newfoundland fisheries. We are sadly in need of education along fishery lines. Our school curriculum needs a thorough overhauling and a place found for such subjects as will divert attention to the fisheries and impart knowledge and information of such a nature as to stimulate interest and create a desire to carefully study matters affecting the fisheries. We need scientific instruction that will produce educated fishermen of a class that any country might be proud of. We now educate our boys to prepare for 
any calling but that of their fathers, what we need is to educate them to realize that a fisherman planter is one of the most valuable citizens this country can produce. Steps must also be taken to make it easy for any young man desiring the same, to obtain an education in the theory of navigation. Our young fishermen by the very nature of their calling could not be other than expert sailors, and prove themselves admirable masters of vessels coasting the Newfoundland and American seaboard. They are often debarred, however, from commanding foreign vessels owing to the lack of education in the subject of theoretical navigation. Next to ships, the most serious side of our exporting difficulties is the question of sailors and officers with certificates of competency for ocean navigation. I am convinced that with increased attention towards these two points - fishery education and the universal teaching of navigation - we shall arouse an interest amongst our young men that will immensely benefit our country and solve the problem of securing educated fishermen, and thereby ensuring the continued prosperity and development of the fisheries of Terra Nova.

\section{A Standard Cull}

(6) The present system of buying fish talqual is perhaps responsible for more injury to the fishermen and the industry than all other evils combined. To purchase good and bad fish as one quality at the same price is nothing short of placing a premium on inferior cure and assisting carelessness and dissatisfaction. The cure of shore fish has alarmingly deteriorated the past twenty years. Twenty-five years ago the cure contained 60 per cent of No. 1 fish and about 35 per cent No. 2. This year's cure will give about 10 per cent No. 1, 75 per cent No. 2 and 15 per cent No. 3. Unless a standard cull is immediately introduced a situation will present itself sufficiently serious to cause a loss of $\$ 5,000,000$ a year to the Colony, as well as cutting off the most valuable markets for prime cure which are found in Spain and Italy. This problem must be faced as soon as possible and a system devised by law that will encourage the curing of a No. 1 article of food. This season the price of 
No. 1 fish would have been $\$ 11.00$ per quintal had a standard cull been enforced. The abnormal demand abroad caused by war conditions has alone saved the Colony the past two years from disaster. Every fisherman who sells No. 1 fish as talqual deprives himself of two dollars per quintal, in order to provide a good price for the man who sells No. 2 and No. 3 as talqual. The system of buying talqual is absolutely an encouragement of inferior cure and carelessness, it is exactly contrary to the requirements of the Colony. The entire fault lies with exporters who were unwise enough to introduce this system about 15 years ago. There must be no further delay in dealing with this dangerous situation. Its importance exceeds all other considerations. It is now a national issue, serious enough to threaten the financial and commercial future of the Colony.

\section{Developing Markets}

(7) To ensure good prices for an annual average catch of 2,000,000 qtls, markets must be developed and extended; this is another matter of vital concern to the whole Colony, and should be considered without delay. A few active men should be working in all the markets in order to encourage consumption by placing on the market an article that will meet the requirements of customers. New markets await our fishery produce if properly commercialized and an attractive article is produced. The expense will not be great, the benefits will be enormous.

\section{The Fishery Department}

(8) The Department of Fisheries ${ }^{15}$ in this Colony is simply something in name. It at present is an Accounting Department in connection with lighthouses, the issuing of licenses for packing lobsters and salmon and the expenditure of a grant to construct and maintain public wharves and landing slips. It is absolutely useless as a help to the fisheries. It has produced no information or data that has been of any value to the fishermen. It has no scientific department, it has been asleep while the 
cure of fish has become a reproach to the Colony. ${ }^{16}$ Lately it has attempted to set up a standard for Refined Cod Liver Oil and Herring - in both of which it has proved its incapacity. One of the imperative duties incumbent upon the present administration of public affairs is to reorganize this department and make it beneficial, instructive, scientific and practical, to do the work that awaits a department that should be the most important and beneficial of all public departments in a country that depends upon the fisheries for 90 per cent of its entire exports. I have not one word to say in favour of continuing the Fishery Dept. in its present impotent condition. I emphatically protest against its continuation as it is; and I urge all who can place country first in their public capacity to take up this matter of reorganizing the Fishery Department seriously and promptly. We should endeavour to place the first fishing country in the world in a position worthy of her wealth and inexhaustible marine resources, and thereby build up a happy, contented and prosperous Terra Nova, providing full and plenty for a population four times greater than it is today.

The time allotted to this subject is 15 minutes. I have probably exceeded the limit, if so, I ask to be forgiven, as the subject is one that might cover an hour and then only the fringes would be touched.

\section{Acknowledgement}

I would like to thank Dr. Hans Rollmann (Memorial University) and Dr. Peter Neary (University of Western Ontario) for their comments on an earlier version of this document.

\section{Notes}

$1 \quad$ Evening Advocate, 31 Dec. 1917.

2 William Coaker (1871-1938). See Ian D.H. McDonald, "To Each His

Own": William Coaker and the Fishermen's Protective Union in Newfoundland Politics, 1908-1925 (St. John's: ISER Books, 1987); Melvin Baker, "William Ford Coaker, the Formative Years, 1871-1908," 
Nerwfoundland and Labrador Studies 27, no. 2 (Fall 2012): 225-66; Melvin Baker, "Coaker, Sir William Ford," in Dictionary of Canadian Biography, vol. 16, University of Toronto/Université Laval, 2003-, http://www.biographi.ca/en/bio/coaker_william_ford_16E.html.

3 Robert Bond (1857-1927). See Melvin Baker and Peter Neary, "Sir Robert Bond (1857-1927): A Biographical Sketch," Nerwfoundland Studies 15, no. 1 (Spring 1999): 1-54.

4 Edward Patrick Morris (1859-1935). See James K. Hiller, "Morris, Edward Patrick, 1st Baron Morris," in Dictionary of Canadian Biography, vol. 16, University of Toronto/Université Laval, 2003-, http://www.biographi.ca/en/bio/morris_edward_patrick_16E.html. William Lloyd (1864-1937), prime minister 1918-19. In January 1918 Lloyd replaced Morris as prime minister.

6 On reform in this period, see James Overton, "Self-Help, Charity, and Individual Responsibility: The Political Economy of Social Policy in Newfoundland in the 1920s," in James Hiller and Peter Neary, eds., Twentieth-Century Newfoundland: Explorations (St. John's: Breakwater, 1994), 79-85; Sean Cadigan, Death on Two Fronts: National Tragedies and the Fate of Democracy in Nerwfoundland, 1914-1934 (Toronto: Allen Lane, 2013), 21-31, 168-229; James K. Hiller, "Social Issues in Early 20th Century Newfoundland: A Comparison of Wilfred Grenfell and William Coaker," Nerwfoundland Quarterly 89, no. 1 (Fall 1994): 27-31; Mike O’Brien, "Producers versus Profiteers: The Politics of Class in Newfoundland during the First World War," Acadiensis 40, no. 1 (Winter/Spring 2011): 45-69.

7 Previously, in 1915 they and Coaker, a teetotaler, had successfully played a strong role in a national plebiscite that secured majority support for prohibition and the enactment of legislation in 1916 for this purpose. See Rev. Dr. Jones, "Why We Won Prohibition," Mail and Advocate, 18 Dec. 1915, where he wrote: "we won Prohibition this year mainly because of this New Social Conscience.... The benefits of this social reform we cannot at present do more than prophecy." See also Melvin Baker, "1921 Report of the Commission on the Prohibition Plebiscite Act," Nerwfoundland and Labrador Studies 27, no. 2 (Fall 2012): 267-79.

8 Walter Edward Davidson (1859-1923), Governor of Newfoundland, 1913-18. 
9 For dimensions of the Canadian social gospel, see Richard Allen, The Social Passion: Religion and Social Reform in Canada, 1914-28 (Toronto: University of Toronto Press, 1971); http://www.thecanadianencyclopedia.ca/en/article/social-gospel/.

10 They were Canadians Rev. Canon L.N. Tucker (Church of England St. Paul's Cathedral, London, Ontario), Rev. T. Albert Moore (General Secretary, Social Service \& Evangelism, the Methodist Church of Canada), Rev. J.G. Shearer (Superintendent of Social Services, the Presbyterian Church of Canada), and Americans Dr. Hastings H. Hart (New York) and Dr. Alexander Johnson, General Secretary of the National Board of Social Service from Philadelphia.

11 Daily Nerws, 8 Oct. 1917.

12 Ibid.

13 See Robert Hong, “'An Agency for the Common Weal': The Newfoundland Board of Trade, 1909-1915" (MA thesis, Memorial University, 1998).

14 Local revenue was derived from a government import tariff.

15 First established in 1898 as part of a reorganization of government departments.

16 On various scientific efforts in this period, see Melvin Baker and Shannon Ryan, "The Newfoundland Fishery Research Commission, 1930-1934," in James E. Candow and Carol Corbin, eds., How Deep Is the Ocean? Historical Essays on Canada's Atlantic Fishery (Sydney, NS: University College of Cape Breton for the Louisbourg Institute, 1997), 161-73. 